\begin{tabular}{|c|c|}
\hline 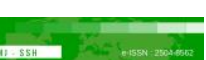 & Malaysian Journal of Social Sciences and Humanities (MJSSH) \\
\hline Malaysian Journal of & Volume 6, Issue 4, April 2021 \\
\hline (MJ-sSH) & e-ISSN : 2504-8562 \\
\hline & $\begin{array}{l}\text { Journal home page: } \\
\text { www.msocialsciences.com }\end{array}$ \\
\hline
\end{tabular}

\title{
Reader-Response Theory: A Systematic Literature Review
}

Sugitha A/P Kunjanman', Azlina Abdul Aziz'

1Faculty of Education, Universiti Kebangsaan Malaysia (UKM)

Correspondence: Sugitha A/P Kunjanman (sugithakunjanman2019@gmail.com)

\begin{abstract}
This paper presents an analysis of a systematic review of relevant published past research on the reader's response theory. The studies reviewed are from the year 2013 to 2020 with the total number of fourteen studies. The main aim of this systematic review is to depict an empirical information formulation discovered through multiple methods in previous scholarly research on the Reader's Response Theory. This systematic study addresses the current findings in reader response theory. The findings focus on the benefits of using the reader-response theory as well as the challenges of faced by a few researchers.
\end{abstract}

Keywords: reader-response theory, reader-response approach, teaching literature in English, research on reader-response.

\section{Introduction}

The reader-response theory is deeply rooted in the cognitive-constructivist view of learning. The theory first emerged in the 1930s and gained popularity in the 1960s and 1970s (Powell and Kalina,2009; Roen and Karolides,2005). The theory was first developed by Louise Rosenblatt (Rosenblatt,1938,1978) and stresses on the cruciality of the reader in making meaning from a text. This based on the premise of readers breathing in life into the texts using their prior knowledge and personal experiences (Larson, 2009). The reader response theory supports the process of making readers critical, thoughtful and engaged (Woodruff and Griffin, 2017). This systematic review aims to present a synthesis of empirical evidence from related studies found over the years on the theory and advantages and challenges found in the studies reviewed. This data will provide crucial information for further research can be conducted in this field of study. With that, the research question below will be the focus of this paper:

1. To identify the advantages of the reader response theory in teaching literature

\section{Literature Review}

\section{Reader's Response Theory}

First emerging in the 1930s, the reader-response theory gained popularity almost thirty to forty years later and is deeply connected to the cognitive-constructivist form of learning (Powell\& Kalina,2009; Roen \& Karolides,2005). The theory acknowledges the varied interpretations that readers might have on literary works in this this top-down model (Graves et.al, 2011). Students are, therefore, valued and 
encouraged to interpret literary works and arrive at their own independent conclusions. It was I.A Richards who discussed one's emotional response towards literature. This was closely followed by the conceptualization of the reader-response theory (RRT) was in the 1920s. This concept was later further advanced by D. W. Harding and L. Rosenblatt in the 1938, and by the 1978, with more rigorous emphasis given to the readers and their experience of the text in works by Norman Holland, Stanley Fish, Wolfgang Iser and Hans-Robert Jauss. In her book, Literature as Exploration (published in 1938), Rosenblatt asserted her view of the reader playing a vital role in any piece of literature. Her transactional theory of reading emphasized the relationship between reader and text whilst constructing meaning. Larson's (2009) definition of reader response is that moment when readers breathe life into texts through their prior knowledge and personal experiences. Dewey's (1946) epistemological writings, transaction, imply that, during the reading process, the self of the reader and the text are more flexible. Thus, according to the Reader Response Theory, the act of constructing meaning is a personal literary experience and a major characteristic that connects the reader and the text. Padley (2006) also acknowledges that in the reader-response theory, "the reader plays the role of an agent who assigns meaning whilst experiencing the text". This theory focusses on the approaches and techniques that are involved in studying how readers respond to a piece of literature and at the same time addresses the strategies used by those readers. This leads to the implication that teachers can create better readers by permitting the possibility of more than once chance to recreate the meaning of a story in their own particular style. This statement is further supported by Woodruff and Griffin (2017) who mentioned that this theory supports the process for students to be engaged, thoughtful and critical readers. Hirvela (1996, p.133) actually proposed a shift in the style of questioning the teacher could use, for example, instead of asking "What does the author mean?" the teacher should ask "How did you feel when reading?" This is because at the secondary stage of development, students have already established their opinions about reading; either they love reading or they do not (Hendrix and Griffin,2017). One such popular method in deriving personal interpretations of a literature text as suggested by Oster (1989) is using a literary journal. A reading log or a journal enables learners to express their feelings, ideas, opinions and interpretations in written form and makes them to become actively involved in the learning process. This is because they would be more aware of the process of responding to the text, but they would also be "testing hypotheses and formulating and altering the meaning of the text for the reader" (ibid.). This in turn would activate learning as students will be forced to ask questions that "demand not just recall but higher-level reasoning and predicting and sometimes demonstrating reflective reading and writing behaviour" (Rosenblatt, 1985).

\section{Models of Teaching Literature}

The teaching of literature can be generally seen through the three models presented by Carter and Long (1991). The Cultural Model is a more traditional approach to teaching literature which leads learners to the discovery and inference of the social, political, literary and historical context of a chosen text. This approach also leads to the understanding of universal thoughts and ideas besides immersing them in differing cultures and ideologies in comparison to their own. As mentioned earlier, it is a traditional approach to the teaching of literature therefore it puts the teacher as the focus and source of facts.

The Language Model is a systematic and methodical approach to the chosen text. Here, the approach allows educators to employ strategies used in language teaching in order to deconstruct literary texts that serves specific linguistic goals. Savvidou (2004) opined that students' engagement with the chosen text merely for linguistic practice and thus makes literature usage purely mechanical in order to provide a series of language activities.

The Personal Growth Model focusses on the personal development of the learner that includes their emotions and personal characteristics. Learners are required to relate and respond to the themes and issue by connecting them to their personal life experiences. This is largely influenced by the cultural model and the language model where focus is laid on the use of a language in a text in a particular cultural context.

It was Carter and Long (1991) who placed importance on connecting the literature with culture. Literature is specifically placed in a specific context so as the students may attain meaning seamlessly. The teacher functions as the director and controller who focusses on the context of the text. Attempts may be made 
by the students to create a bond between their personal lives in attempting to create their own literary work as attempting to write a simple poem or a simple short story that may narrate and support the same themes of the novel or the literary text. By creating such an opportunity for the students to interact with the text, it enhances their language competence and develops their literary skills. Through personal growth, the literary text creates not only love but also loyalty that transcends beyond the classroom. It develops students' critical appreciation and assessment skills that prepare the student to well critical appreciation and well reading of the literary text.

\section{Approaches to teaching literature: Reader-response approach}

Carlisle's (2000) research on EFL learners, said the reader-response approach "encourages EFL learners to study literature for the sake of literature rather than for the mere language skills attainment". This approach's focus is on the reader's response to the text. With the employment of this approach, educators will be able to see a transitional relationship between the reader's opinions, feeling and their personal experiences. This approach allows reading to be considered as a conversation with the text whereby multiple interpretations are allowed as well as encouraged and the focus of the text can be viewed from an array of perspectives. With accordance to this, the reader-response approach provides a studentfocussed and process-oriented classroom. Approaches in the classroom are crucial as they function to help us to select and design materials for classroom use and to assess the suitability of published materials. Approaches are very important for the teachers in designing classroom activities. It helps to make classroom teaching effective. Rosenblatt (1968) and Iser (1979) defined reader response as an approach that takes into consideration of the students' personal response to a text, allows literature to be relevant to students' life and multiple interpretation can be accepted rather than just one definite interpretation. The reader response approach promotes reflective thinking and creativity in literature classroom. Besides that, the reader response approach motivates students to learn literature for the advantages it carries and not just for the purpose of mastery in language skills. Research done by Harfitt and Chu (2011) brought forward the importance of reader response approach in promoting self-learning as it opens students to self-interpretation and tells the story from their point of view rather than depending solely on the teacher to provide an interpretation. Enabling students to think for themselves also encourages critical thinking. Ali (1993) concluded that every students' interpretation will be unique as the reflection is influenced by their backgrounds and beliefs that differ from one another.

\section{Methodology}

To reach the objectives of this systematic literature review, 15 papers related to the topic were carefully selected from various sources to be analyzed. Based on the steps carried out by Khan et.al (2003), there are basically five steps in conducting a systematic review. Number one would be the framing of the research questions by the researcher. The researcher conducting the research needs to be clear with the issues that are being presented and should be able to construct concise and straightforward research questions free of ambiguity. The second step would be to identify and collect relevant work within the chosen field. In order to do this, an extensive search needs to be done o include studies from multiple sources. In this systematic review, the researcher opted to use the peer-reviewed research databases mainly Educational Resources Information Centre (ERIC) and Google Scholar to look for research studies or articles published from the year 2013-2020. The selection of suitable materials leaned on 'reader response theory', 'reader response approach' and other suitable keywords. In the event the researcher comes across a suitable article, the researcher proceeds to click "related articles" to seek out other articles of relevance. Step number three requires the researcher to assess the quality of the studies to see if they meet certain fixed criteria. In order to ensure the selected articles are relevant in answering the research questions, the researcher can opt to decide the criteria that needs to be included and excluded to be tabulated if need be. The second last step in this systematic review is to summarise the evidence and this was done with the use of a table. The final step, once the researcher is done with the execution of the other steps, is to interpret the findings based using the method of comparing the information gathered. The information is then tabulated to ease the process of answering the research question. 


\section{Result}

Fourteen studies or articles from the year 2013 to 2020 were shortlisted based on the review question. All the articles or studies are related to the reader's response theory in teaching literature. The results have been tabulated and presented in the table below.

Table 1: Findings from studies related to the reader's response theory in teaching literature

\begin{tabular}{llll}
\hline Author \& Year & \multicolumn{1}{c}{ Research Design } & \multicolumn{1}{c}{ Results } \\
\hline Vijayarajoo \& & Case Study & $\bullet$ & Results showed that after participants took part in the \\
Samuel & (22 Pre-TESL students) & $\begin{array}{l}\text { reader response activities, there was a shift in the } \\
\text { (2013) }\end{array}$ & $\begin{array}{l}\text { stances, from efferent to aesthetic. } \\
\text { - }\end{array}$ \\
& & $\begin{array}{l}\text { Students moved from merely reporting the facts of the } \\
\text { story to commenting personally on the characters and } \\
\text { this is evident of how emotionally involved they were } \\
\text { with the story. }\end{array}$
\end{tabular}

Farahian \& Experimental study

Farshid (75 Iranian

(2014) intermediate students)

Utami (2014) Experimental study (184 students)
Garzon \&Peńa Qualitative Research (2015)

-questionnaire -classroom discussion -research interview (7 participants)
- Reader-response theory allows students to be more purposeful and active readers of texts.

- Students become more critical of the text

- Students used various methods such as over-viewing the text before reading, activating prior knowledge, an visualizing - metacognitive reading strategies.

- Students' reading comprehension ability improved as evidenced by their activeness in reading.

- Good teaching strategies can motivate students' to read more deeply and make meaningful connection with texts.

- Students have ample opportunity to interpret the texts as well as engage in a many activities that can make use of their opinions, personal experience and their prior knowledge.

- Students with low reading interest can also benefit through small group discussions because their experiences and opinions are valued.

- Students expressed affective achievement and were able to evaluate ideas.

- They read with attention in search for answers to the questions that rose in their first reading of the text.

- Participants reflected on their own experiences, attitudes and observations in relation to what they read in the texts, putting aspects of the stories into a larger context.Interpretive responses were apparent through participants' attempts to make meaning of the stories based on what was explicitly stated in the text. 


\begin{tabular}{|c|c|c|}
\hline & & $\begin{array}{l}\text { Participants tried to make meaning of the story based } \\
\text { on what was implicit. This was a demonstration of } \\
\text { inferential responses. }\end{array}$ \\
\hline $\begin{array}{l}\text { Chou I-Chia } \\
(2015)\end{array}$ & $\begin{array}{l}\text { Qualitative study } \\
\text { (15 undergraduate } \\
\text { students) }\end{array}$ & $\begin{array}{l}\text { - E-books have gained popularity as a pedagogical } \\
\text { tool. } \\
\text { - Aesthetic connections were made with the text. } \\
\text { - Students were able to express opinions and their } \\
\text { appreciation for literature. }\end{array}$ \\
\hline $\begin{array}{l}\text { Iskhak } \\
\text { (2016) }\end{array}$ & $\begin{array}{l}\text { Classroom Action } \\
\text { Research } \\
\text { (36 teacher trainees) }\end{array}$ & $\begin{array}{l}\text { - Students' perception of the past and their tendency } \\
\text { to personalize their connection to the text were the } \\
\text { results of the stimulating tasks and questions } \\
\text { - Active discussion led the students to share their } \\
\text { ideas and dialogue with each other. } \\
\text { - Participants displayed heightened self-confidence } \\
\text { and were able to speak more fluently in the target } \\
\text { language as the sessions took place. }\end{array}$ \\
\hline $\begin{array}{l}\text { Marselina } \\
\text { Nugraheni } \\
\text { Fitrisari } \\
(2016)\end{array}$ & $\begin{array}{l}\text { Qualitative research } \\
\text { based on reader } \\
\text { response } \\
\text { (300 respondents) }\end{array}$ & $\begin{array}{l}\text { - An investigation into readers responses to racism } \\
\text { based on feedback left on a Goodreads. } \\
\text { Breakdown of user responses based on gender, } \\
\text { geographical location, age, race, religion etc. } \\
\text { - Analysis of said breakdown into } 18 \text { dominant issues } \\
\text { based on the Reader Response Theory }\end{array}$ \\
\hline $\begin{array}{l}\text { Iskhak et.al } \\
\text { (2017) }\end{array}$ & $\begin{array}{l}\text { Quantitative study } \\
\text { (22 students) }\end{array}$ & $\begin{array}{l}\text { - Participants' critical thinking skills developed } \\
\text { significantly after their journal intervention. } \\
\text { - They wrote more 'auhoritatively' and originally after } \\
\text { the intervention. } \\
\text { - Participants were more actively engaged in the } \\
\text { process of making meaning and connections with } \\
\text { their readings. }\end{array}$ \\
\hline $\begin{array}{l}\text { Fathu Rahman } \\
\text { (2017) }\end{array}$ & $\begin{array}{l}\text { Survey based study } \\
\text { (257 students) }\end{array}$ & $\begin{array}{l}\text { - Investigation of student opinion on Facebook as a } \\
\text { medium for promoting cyber literature } \\
\text { - Writers can get immediate feedback and critiques of } \\
\text { their works. }\end{array}$ \\
\hline $\begin{array}{l}\text { Ivan Botev } \\
\text { (2017) }\end{array}$ & Case Study Analysis & $\begin{array}{l}\text { - Analysis of Reader Response Theory in books } \\
\text { containing multimodal texts. } \\
\text { - Accounting for responses to images as well as text in } \\
\text { the analysis. } \\
\text { - Placing importance on user participation. }\end{array}$ \\
\hline $\begin{array}{l}\text { Dilek Inan } \\
\text { Merve Nur } \\
\text { Boldan } \\
(2018)\end{array}$ & $\begin{array}{l}\text { Qualitative research } \\
\text { based on reader } \\
\text { response } \\
(50 \text { students })\end{array}$ & \\
\hline
\end{tabular}


Elena Spirovska Qualitative research (2019) based on reader response (22 students)

Rina Wiryadi (2020)

\section{Qualitative research based on reader reviews on the Goodreads website (20 reviewers)}

Affendi \& Aziz Systematic Review (2020)
- Analysis found 3 common responses from students: Literature as content, language-based and literature for personal enrichment.

- Student productivity in literature can be encouraged by using RRT

- RRT is useful in reducing teacher prejudice against literature.

- Implementing the RRT for the teaching of literature to students

- Measuring student reactions using the developmental model

- Conclusion of RRT in literature is that it leads to greater student participation, awareness and responsiveness

- Using Reader Response on a novel to analyze female empowerment.

- Dividing responses based on gender, year and geographical location

- Constant changes made to selection of texts through the years posed a challenge. Text selections need to ensure that student uptake and engagement are encouraged.

- Contexts and themes have been found to be unrelatable to students. Texts selected have also proven to be 'culturally and contextually foreign' (Omar, 2017)

- In the matter of poetry, studies found that the language used was tough and therefore students couldn't enjoy the texts.

- Teachers' limitations in their knowledge of the texts led to their weak deliveries of lessons.

- Studies found that teachers preferred the paraphrastic approach, information-based, and moral-philosophical approaches.

- Their least preferred approaches were the languagebased approach and the personal response approach.

- Students also found web-based applications were usefi when integrated into literature lessons 


\section{Discussion}

The researcher would like to highlight the advantages of using the reader-response theory in teaching literature:

i. Promotes students' ability to give personal responses to a text

ii. Promotes reflective thinking and creativity in the literature classroom

iii. Motivates students to learn literature for its advantages

iv. Promotes self-learning, higher-level reasoning, self-interpretation and predicting

Students can reflect on their own experiences, attitudes and observations (Garzon and Pena 2015) in relation to what they read in the text, putting aspects to what they read in the text. This is a particularly important skill that need to be developed in a young adult learner. 13 of the studies above have reported the effectiveness of the reader-response theory in the literature classroom. Students were not only able to express and evaluate ideas (Garzon and Pena 2015) but they demonstrated the use of inferential responses. The display of inferential responses is clearly seen in 5 studies above namely, the studies done by Ishak (2015), Vijayarajoo and Samuel (2013), Chou (2015), Ishak et. al (2017), and Utami et. al. (2014) and. Inferential responses refer to interpretive responses that clearly indicates the participants attempts to make meaning of the text read. Ishak's 2015 action research which involved 36 trainee teachers found that students had the tendency to personalize their connection with their past as a result of stimulating tasks and questions. Vijayarajoo and Samuel's (2013) findings also noted a shift in the participants stances from efferent to aesthetic. The case study which involved 22 Pre-TESL students was reported to have moved students from merely commenting to being emotionally involved with the short stories. Chou (2015) indicated aesthetic connections being made in his findings even with the use of Ebooks in his qualitative study involving 15 undergraduate students. Besides that, the studies also indicate a heightened sense of confidence amongst the participants as found in 14 of the studies. 36 trainee teachers in Iskhak's 2015 study revealed active discussions that led to a dialogue and sharing of ideas. Iskhak et.al (2017)'s study also went on to reveal finding where the 22 students wrote more authoritatively in their journals after the intervention. Utami's (2014) experimental study of 184 students showed findings of improved reading comprehension ability as evidenced by their activeness in reading. The studies also indicated the improved speaking ability amongst the participants who underwent the reader-response approach. 4 studies have been listed as revealing findings that support this. Iskhak's (2015) study indicated active discussions that led to the 36 teacher trainees to the sharing of ideas and dialogues with each other. Participants also displayed an elevated sense of confidence and were able to communicate more fluently in the target language. Similarly, Chou's (2015) study on 15 undergraduate students and Botev's (2017) case study analysis revealed the ability to express opinions, placing importance on user participation. Sprirovska's (2019) research on 22 students using the reader-response theory with a developmental model to teach literature indicated greater student participation, awareness as well as responsiveness. 3 studies highlighted on findings that showed improvement in reading comprehension by the participants. Garzon and Pena (2015). Farahian and Farshid (2014) and Utami ((2014) all provided evidence of participants reading with better attention in search of answers even after the first reading of the text in the 16-week study as shown by the 7 participants in Garzon and Pena's (2015) study. Meanwhile, in the experimental study done by Farahian and Farshid (2014) on 75 intermediate-level Iranian students, findings showed reading to be more purposeful and brought about more active readers. The students also portrayed the usage of various reading methods to aid comprehension such as visualizing (a metacognitive reading strategy). Utami's (2014) experimental study showcased the 184 students displaying activeness in reading which was reported to be motivated by good teaching strategies and meaningful connection with the text. Students with low reading interest also benefitted through the discussions conducted. This also echoes Inan and Boldan's (2018) research on 50 pre-service students using qualitative and thematic analysis which found the RRT useful in encouraging student productivity by using three approaches such as, literature as content, language-based and literature for personal enrichment. 


\section{Conclusion}

Based on the systematic review, it can be concluded that the advantages of using the Reader-response theory in teaching literature are numerous and can be concluded as follows:

i. Promotes students' ability to give personal responses to a text

ii. Promotes reflective thinking and creativity in the literature classroom

iii. Motivates students to learn literature for its advantages

iv. Promotes self-learning, higher-level reasoning, self-interpretation and predicting

\section{Limitation and Recommendation}

Whilst conducting the systematic review, a few limitations were highlighted based on the studies researched by Affendi and Aziz (2020). The studies involved could have focused on Malaysian literature classrooms as the majority of the studies highlighted were outside of Malaysia. Changes made to text selection over the years have made it difficult for teachers as well as students to be kept engaged. This is because some of the students find the contexts and themes unrelatable. Besides that, limited knowledge by the teachers also contributed to the weak delivery of lessons which also affected student engagement. In line with the moving times, students also displayed a penchant for using web-based applications in literature lessons therefore sidelining the use of physical books however this should not hinder the ability of the teacher to incorporate interesting meaningful lessons into their classrooms. As for the recommendations for future researcher and teachers alike, it is recommended that more research to be conducted using students of different proficiency level or socio-economic backgrounds and according to gender. Also, studies involving students of differing levels of proficiencies and gender may be able to provide curriculum developers and teachers with valuable information to better meet the students' need and experience the advantages of learning literature in a more meaningful manner. This includes the selection and designing of suitable materials, assessing the suitability of the published materials and the designing of effective classroom activities and questions that are stimulations for the students or participants.

\section{References}

Affendi, F. R., \& Aziz, A. A. (2009). Systematic Review: The Challenges and Approaches in The Teaching of English Literature in Enhancing English Proficiency.

Ali, S. (1993). The reader-response approach: An alternative for teaching literature in a second language. Journal of Reading, 37(4), 288-296.

Carlisle, A. (2000). Reading logs: An application of reader-response theory in ELT.

Carter, R., \& Long, M. (1991). Teaching literature. Oxford: Oxford University Press.

Chou, I. C. (2015). Engaging EFL students in e-books using reader-response theory. The Reading Matrix: An International Online Journal. Wenzo Ursuline University of Languages.

Dewey, J., \& Bentley, A. F. (1946). Interaction and transaction. The journal of philosophy, 43(19), 505517.

Farahian, M., \& Farshid, M. (2014). A Reader-Response Approach to Reading: Does It Have an Effect on Metacognitive Reading Strategies?. Modern Journal of Language Teaching Methods, 4(1), 371.

Fitrisari, M. N., \& Thoyibi, M. (2016). Reader Response to Racism In Harper Lee's Novel: To Kill A Mockingbird (1960) (Doctoral dissertation, Universitas Muhammadiyah Surakarta).

Garzón, E. \& Castañeda-Peña, H. (2015). Applying the Reader Response Theory to Literary Texts in EFL-Pre-Service Teachers' Initial Education. Canadian Center of Science and Education 8(8), 187- 198.

Graves, M. F., Juel, C., Graves, B. B., \& Dewitz, P. (2011). Teaching reading in the 21st century: Motivating all learners. Pearson.

Harding, D. W. (1962). Psychological processes in the reading of fiction. The British Journal of Aesthetics, 2(2), 133-147. 
Harfitt, G., \& Chu, B. (2011). Actualizing reader-response theory on L2 teacher training programs. TESL Canada Journal, 93-103.

Hendrix, R. A., \& Griffin, R. A. (2017). Dedveloping enhanced morphological awareness in adolescent learners. Journal of Adolescent \& Adult Literacy, 61(1), 55-63.

Hirvela, A. (1996). Reader-response theory and ELT. ELT Journal, 50(2), 127-134.

Iskhak, I. (2016). The application of reader-response theory in enhancing student teachers' affective and linguistic growth: A classroom action research in EFL teacher education in Indonesia. The English Teacher, 2, 13.

Iskhak, I., Saleh, M., Sofwan, A., \& Hartono, R. (2017). Investigating the Effects of Reader Response Journals on the Quality of Teacher Trainees' Responses to Literary Works. Theory and Practice in Language Studies, 7(10), 831-840.

İnan, D., \& Boldan, M. (2018). Implementation of Reader-Response Theory in Teaching Short Story. The Literacy Trek, 4(2), 63-76.

IVAN, B. (2017). Taking Reader Response Theory to a New Level: Yasuhiro Endoh's Picturebook Read-alouds (yomigatari). 大学院紀要= Bulletin of the Graduate School, Toyo University, 54, 25-37.

Khan, K. S., Kunz, R., Kleijnen, J., \& Antes, G. (2003). Five steps to conducting a systematic review. Journal of the Royal Society of Medicine, 96(3), 118-121.

Larson, L. C. (2009). Reader response meets new literacies: Empowering readers in online learning communities. The reading teacher, 62(8), 638-648.

Oster, J. (1989). Seeing with different eyes: Another view of literature in the ESL class. TESOL quarterly, 23(1), 85-103.

Rahman, F., 2017. Cyber literature: A reader-writer interactivity. International Journal of Social Sciences \& Educational Studies, 3(4), p.156.

Roen, D., \& Karolides, N. J. (2005). Louise Rosenblatt: A life in literacy. ALAN Review, 32(3), 59.

Rosenblatt, L. (1976). Literature as exploration. New York: Modern Language Association of America.

Rosenblatt, L. M. (1985). Viewpoints: Transaction versus interaction: A terminological rescue operation. Research in the Teaching of English, 96-107.

Richards, I. A. (2003). Principles of literary criticism. Routledge

Padley, S. (2006). Key concepts in contemporary literature. Macmillan International Higher Education.

Powell Katherine, C., \& Kalina, CJ (2009). Cognitive and social contructivism: developing tools for an effective classroom. Education, 130(2), 241-25.

Spirovska, E. (2019). Reader-Response Theory and Approach: Application, Values and Significance for Students in Literature Courses. SEEU Review, 14(1), 20-35.

Utami, E., Zaim, M., \& Rozimela, Y. (2014). The effect of reader response strategy and students' reading interest toward students' reading comprehension of narrative text at Grade X SMA 2 Kota Bengkulu. English Language Teaching (ELT), 2(1).

Vijayarajoo, A. R. and Samuel, M. (2013). Reader response pedagogy and changes in student stances in literary texts. The English Teacher, 42(3), 174-186

Woodruff, A. H., \& Griffin, R. A. (2017). Reader Response in Secondary Settings: Increasing Comprehension through Meaningful Interactions with Literary Texts. Texas Journal of Literacy Education, 5(2), 108-116.

Wiryadi, R., \& Chandraningrum, P. D. (2020). Girl's Power Reflected In Rick Yancey's The 5th Wave Novel (2013): A Reader's-Response Theory (Doctoral dissertation, Universitas Muhammadiyah Surakarta). 